\title{
Pengaruh Kepribadian HEXACO dan Tawakal Terhadap Grit Mahasiswa Fakultas Psikologi UIN Jakarta Menghadapi Mata Kuliah Statistika
}

\author{
Fauzan Salmanto \\ Fakultas Psikologi UIN Syarif Hidayatullah Jakarta \\ otnamojan@gmail.com
}

\begin{abstract}
This research was conducted to find out the significance of the HEXACO personality and tawakal on grit on 170 students in Faculty of Psychology UIN Syarif Hidayatullah, Jakarta. Sampling conducted using nonprobability sampling. Instruments used in this study there are three scales, namely Academic Grit scale, Brief HEXACO Inventory Scale, and tawakal scale. Test the validity of the measuring instrument using confirmatory factor analysis (CFA) technique. While the data analysis using multiple regression techniques. The results of this study indicate that there is a significant influence of the trait of HEXACO personality and tawakal on grit in students. The amount of influence of all independent variables on grit is $37.4 \%$, while the rest is influenced by other variables outside this research. While the results of the analysis of the proportion of variance of each variable separately, found the largest contribution to grit is conscientiousness, extraversion, trust to God (Allah), not worry, emotionality, and worship. This research will get better results when using a wider population, to obtain more diverse data and can compare with factors that have not been studied.
\end{abstract}

Keywords: HEXACO, tawakal, grit

\begin{abstract}
Abstrak
Penelitian ini dilakukan untuk mengetahui pengaruh kepribadian HEXACO dan tawakal pada grit pada 170 mahasiswa di Fakultas Psikologi UIN Syarif Hidayatullah, Jakarta. Pengambilan sampel dilakukan dengan menggunakan non-probability sampling. Instrumen dalam penelitian ini menggunakan tiga skala, yaitu skala Academic Grit, Brief HEXACO Inventory Scale, dan skala tawakal. Uji validitas alat ukur menggunakan teknik analisis faktor konfirmatori (CFA). Sedangkan analisis data menggunakan teknik regresi berganda. Hasil penelitian ini menunjukkan bahwa ada pengaruh yang signifikan dari sifat kepribadian HEXACO dan tawakal pada grit di mahasiswa. Pengaruh semua variabel independen terhadap grit adalah 37,4\%, sedangkan sisanya dipengaruhi oleh variabel lain di luar penelitian ini. Hasil analisis proporsi varians dari masing-masing variabel secara terpisah, ditemukan kontribusi terbesar untuk grit adalah conscientiousness, extraversion, keyakinan kepada Allah, tidak khawatir, emotionality, dan ibadah. Penelitian ini akan mendapatkan hasil yang lebih baik ketika menggunakan populasi yang lebih luas, agar diperoleh data yang lebih beragam dan dapat dibandingkan dengan faktor-faktor yang belum diteliti.
\end{abstract}

Keywords: HEXACO, tawakal, grit 


\section{Pendahuluan}

Mempelajari statistika memberikan tantangan bagi peserta didik yang tidak mahir dalam ilmu matematika (Abd Hamid \& Sulaiman, 2014). Dari wawancara singkat yang peneliti lakukan, beberapa mahasiswa sepakat bahwa mata kuliah statistik dirasa cukup sulit, tetapi dirinya terus mencoba mempelajarinya. Selain itu, beberapa mahasiswa menyerah dan hanya cukup berharap untuk hasil terbaik di akhir semester. Data nilai akhir statistik 1 selama empat tahun terakhir dari tiga dosen pengampu yang peneliti dapat dengan mengakses bagian akademik Fakultas Psikologi UIN Jakarta menunjukkan bahwa tingkat kelulusan mahasiswa pada mata pelajaran ini cenderung tinggi. Dalam data tersebut, menunjukkan ada 30-40 mahasiswa tidak lulus mata kuliah statistika 1 setiap tahunnya. Jika rata-rata jumlah mahasiswa setiap kelas di Fakultas Psikologi UIN Jakarta adalah 180 orang, maka diasumsikan bahwa ada sekitar 20\% mahasiswa yang tidak lulus dalam statistik 1.

Mata kuliah statistik itu sendiri adalah matakuliah prasyarat bagi para mahasiswa Fakultas Psikologi UIN Jakarta. Konsekuensi dari kegagalan mahasiswa dalam salah satu mata kuliah statistika adalah mengulangi mata kuliah statistika yang tidak lulus dalam semester ganjil/genap tahun depan. Ini merupakan beban dan menimbulkan kekhawatiran tersendiri bagi peserta didik. Dampak negatif juga dapat menaungi mahasiswa dalam menjalani kursus statistik, yaitu munculnya kecemasan khusus di bidang statistik (Onwuegbuzie \& Wilson, 2003) bahkan gangguan kognitif dalam strategi belajar peserta didik (Macher, et.al, 2012). Sehingga dibutuhkan sedikit perilaku persisten pada peserta didik dalam upaya untuk mempelajari statistik ini (Hill \& Wigfield, 1984).

Jika fokus turun ke tingkat grit atau kegigihan pada peserta didik saat belajar, variabel ini telah terlihat mampu mengantarkan individu untuk mencapai hasil yang lebih baik dan lebih cepat. Duckworth, et.al. (2007) telah mengembangkan dan membuktikan faktor grit sebagai variabel penentu untuk pencapaian pretasi dalam berbagai situasi. Pada pelatihan militer, calon tantara yang direkrut dengan grit rendah telah terbukti menyerah dan memilih keluar dari kamp pelatihan dibandingkan dengan kandidat lain yang telah diuji dengan grit tinggi. Dalam kontes National Spelling Bee, Amerika Serikat, peserta dengan peringkat tertinggi ternyata juga memiliki grit yang lebih tinggi daripada peserta yang meninggal pada awal kompetisi. Ini diketahui setelah menyelidiki cara belajar, mengukur nilai grit peserta, kemudian melihat peserta mana yang keluar sebagai juara lomba mengeja Amerika Serikat. Ada juga siswa di Ivy League University yang menjadi studi berikutnya dari Duckworth yang menemukan bahwa siswa dengan grit tinggi memiliki skor IPK lebih tinggi pada akhir kursus mereka.

Duckworth et al. (2007) bahkan menemukan bahwa grit mengalahkan IQ sebagai prediktor keberhasilan dalam lingkungan akademik. Vainio (2015) mengemukakan bahwa grit dan kebutuhan akan prestasi (need for achievement) adalah konstruksi yang saling terkait atau berkorelasi. Oleh karena itu, peneliti melihat bahwa ketika mahasiswa baru belajar kursus statistik, mereka harus dilengkapi dengan grit.

Banyak penelitian telah mencoba menjelaskan grit tertentu dari prestasi akademik peserta didik. Secara eksplisit, variabel keterlibatan grit signifikan terhadap peningkatan rata-rata nilai mahasiswa (IPK) (Jachimowicz, et.al 2018). Penelitian yang dilakukan oleh Akos dan Kretchmar (2017) juga memiliki hasil yang sama, grit ditempatkan sebagai faktor non-kognitif dalam keberhasilan akademik peserta didik.

Beberapa prediktor yang mempengaruhi grit termasuk konteks kepribadian dan keluarga (Lin \& Chang, 2017), ketahanan (Georgoulas-Sherry \& Kelly, 2019), sosial budaya (Datu, Yuen, \& Chen, 2016), self-efficacy, dan gender (Rojas, Reser, Usher, \& Toland 2012). 
Mendez (2015) berbicara tentang pengaruh sifat kepribadian pada ketekunan, tanggung jawab, kemandirian, dan kerja keras di mana ketekunan adalah dimensi yang terkandung dalam grit. Tesis yang dilakukan oleh Coomer (2016) menunjukkan bahwa kepribadian Hexaco juga memberikan kontribusi positif terhadap pengaruh level grit pada individu. Penelitian ini ingin mengetahui lebih jauh dan membuktikan apakah ada perbedaan atau kesamaan pada pengaruh tipe kepribadian HEXACO terhadap grit.

Javandmard (2013) menunjukkan bahwa kepercayaan agama (religious belief) termasuk menyerah kepada tuhan (surrender to god) adalah prediktor ketahanan pada peserta didik. Hubungan ini menjadi benang merah ketika melihat bahwa ada satu dimensi dalam variabel grit yang sama dengan variabel ketahanan atau kegigihan dalam penelitian tersebut. Penelitian dari Gupta dan Kumar (2015) yang menyatakan bahwa dimensi penerimaan, pengampunan, dan rasa terima kasih dalam tawakal adalah prediktor signifikan dari kegigihan. Habibah, dkk. (2018) menemukan hasil awal bahwa jika seseorang memiliki kecerdasan emosi yang tinggi maka itu tidak akan cukup untuk menambah ketahanan terhadap dirinya sendiri. Tetapi berbeda jika disangga atau ditemani oleh variabel kepercayaan. Kemudian ada peningkatan dengan pengaruh $r=0,49$ sebagai prediktor ketahanan dalam jiwa individu. Selain itu, menurut McDonald dan Gorsuch (dalam Sartika \& Kurniawan, 2014), seseorang dengan nilai tinggi pada variabel penyerahan diri kepada Tuhan atas upaya yang telah dilakukan juga akan memberikan solusi yang tidak terduga untuk menyelesaikan masalah yang mereka hadapi.

Ada banyak penelitian yang telah dilakukan untuk melihat efek grit pada peserta didik, baik pada ketekunan dalam mempelajari bidang tertentu maupun pada peserta didik awal yang baru saja masuk perguruan tinggi. Namun, peneliti belum menemukan literasi ilmiah yang berbicara tentang pengaruh tipe kepribadian dan tawakal pada grit pada individu. Selain itu, tidak ada penelitian khusus tentang membahas perjuangan mahasiswa yang mengambil mata kuliah statistika. Itulah sebabnya penelitian ini hadir untuk menyelidiki pengaruh kepribadian HEXACO dan tawakal pada jiwa grit mahasiswa dalam mata kuliah statistik.

\section{Metode}

Penelitian ini menggunakan pendekatan kuantitatif dengan analisis regresi berganda. Populasi dalam penelitian ini adalah mahasiswa Fakultas Psikologi UIN Jakarta Angkatan 2019. Pengambilan sampel dalam penelitian ini menggunakan teknik non-probability sampling, yaitu sampling jenuh (Sugiyono, 2007) dimana semua orang dalam populasi (185 siswa) diharapkan dapat mengambil data. Dalam prosesnya, sampel yang terjangkau dalam penelitian ini berjumlah 170 orang.

Instrumen pengukur grit yang disusun dalam penelitian ini merujuk pada Academic Grit Scale yang dikembangkan oleh Rojas, et.al., (2012) dengan 10 item. Kemudian, alat ukur untuk mengukur sifat kepribadian HEXACO mengadaptasi 24 item Brief HEXACO Inventory dari de Vries (2013). Lalu alat ukur untuk mengukur tingkat Tawakal dalam penelitian ini memodifikasi skala konstruk tawakal Sartika \& Kurniawan (2015) dengan 25 item.

Untuk menguji hipotesis penelitian, penulis menggunakan analisis regresi berganda. Dalam hal ini variabel yang digunakan sebagai DV (variabel yang dianalisis untuk varians) adalah grit, sedangkan IV (prediktor) adalah honesty-humility, emotionality, extraversion, agreeableness, conscientiousness, dan openness to experience, yakin pada Allah, tidak khawatir, dan beribadah. 


\section{Hasil}

Berdasarkan tabel 1, dapat dilihat bahwa nilai R-Square adalah 0,374 atau 37,4\%. Nilai ini berarti bahwa proporsi variabel grit yang dapat dijelaskan oleh variabel kepribadian HEXACO (honestyhumility, emotionality, extraversion, agreeableness, conscientiousness, dan openness to experience) dan Tawakal (yakin pada Allah, tidak khawatir, dan beribadah) adalah 37,4\%. Sedangkan sisanya, $62,6 \%$ proporsi variabel grit dipengaruhi oleh variabel lain di luar penelitian ini.

\section{Tabel 1}

$R$ Square

\begin{tabular}{ccccc}
\hline \multicolumn{5}{c}{ Model Summary } \\
\hline Model & $\mathbf{R}$ & R Square & Adjusted R Square & Std. Error of the Estimate \\
\hline 1 & $.611^{\text {a }}$ & .374 & .339 & 6.74918 \\
\hline \multicolumn{3}{r}{ a. Predictors: (Constant), Ibadah, Emotion, Openness, Honesty, Agree, YAKIN, Extra, Khawatir, Conscien }
\end{tabular}

Pada tes kedua, peneliti menguji apakah seluruh variabel independen memiliki efek signifikan terhadap grit. Hasil uji F dapat dilihat pada tabel 2:

Table 2

Anova pengaruh seluruh IV terhadap DV

\begin{tabular}{|c|c|c|c|c|c|c|}
\hline \multicolumn{7}{|c|}{ ANOVA $^{\mathbf{a}}$} \\
\hline \multicolumn{2}{|c|}{ Model } & \multirow{2}{*}{$\begin{array}{r}\text { Sum of Squares } \\
4349.931\end{array}$} & \multirow{2}{*}{$\begin{array}{r}\text { df } \\
9\end{array}$} & \multirow{2}{*}{$\begin{array}{r}\text { Mean Square } \\
483.326\end{array}$} & \multirow{2}{*}{$\begin{array}{l}\mathbf{F} \\
10.611\end{array}$} & \multirow{2}{*}{$\begin{array}{l}\text { Sig. } \\
.000^{\mathrm{b}}\end{array}$} \\
\hline 1 & Regression & & & & & \\
\hline & Residual & 7288.233 & 160 & 45.551 & & \\
\hline & Total & 11638.165 & 169 & & & \\
\hline
\end{tabular}

Berdasarkan uji-F pada tabel 2, dapat dilihat bahwa tingkat signifikansi (p) di kolom paling kanan adalah $\mathrm{p}=0,000$. Dengan nilai Sig <0,05, maka itu membuat hipotesis utama yang berbunyi "ada pengaruh tipe kepribadian HEXACO dan tawakal pada grit" dapat diterima. Dalam hal ini, ada pengaruh yang signifikan dari variabel kepribadian HEXACO HEXACO (honesty-humility, emotionality, extraversion, agreeableness, conscientiousness, dan openness to experience) dan Tawakal (yakin pada Allah, tidak khawatir, dan beribadah) pada variabel dependen yaitu grit dalam penelitian ini.

Pada langkah terakhir, peneliti melihat koefisien regresi masing-masing IV. Jika sig <0,05, koefisien regresi signifikan, yang berarti bahwa variabel independen memiliki pengaruh signifikan terhadap grit. Besarnya koefisien regresi dari setiap variabel independen pada grit dapat dilihat pada tabel 3: 


\begin{tabular}{|c|c|c|c|c|c|c|}
\hline \multicolumn{7}{|c|}{ Coefficients $^{\mathrm{a}}$} \\
\hline \multicolumn{2}{|c|}{ Model } & \multicolumn{2}{|c|}{ Unstandardized Coefficients } & Standardized Coefficients & \multirow[t]{2}{*}{$\mathbf{t}$} & \multirow[t]{2}{*}{ Sig. } \\
\hline & & B & Std. Error & Beta & & \\
\hline \multirow[t]{10}{*}{1} & (Constant) & 26.467 & 10.114 & & 2.617 & .010 \\
\hline & Honesty & -.103 & .076 & -.093 & -1.370 & .173 \\
\hline & Emotion & -.137 & .080 & -.115 & -1.719 & .088 \\
\hline & Extra & .099 & .071 & .097 & 1.399 & .164 \\
\hline & Agree & .042 & .083 & .034 & .509 & .611 \\
\hline & Conscien & .338 & .090 & .276 & 3.766 & $.000 *$ \\
\hline & Openness & .039 & .087 & .029 & .453 & .651 \\
\hline & YAKIN & -.173 & .073 & -.162 & -2.369 & $.019 *$ \\
\hline & Khawatir & .179 & .068 & .193 & 2.645 & $.009 *$ \\
\hline & Ibadah & .187 & .070 & .191 & 2.665 & $.008 *$ \\
\hline
\end{tabular}

Dari tabel ini, dapat dilihat bahwa ada empat variabel dalam penelitian ini yang memiliki nilai koefisien regresi yang signifikan, yaitu: (1) conscientiousness, (2) Yakin pada Allah, (3) tidak khawatir, dan (4) beribadah.

\section{Kesimpulan}

Berdasarkan hasil analisis data untuk menguji hipotesis penelitian, hasil penelitian menunjukkan bahwa ada pengaruh signifikan kepribadian HEXACO (honesty-humility, emotionality, extraversion, agreeableness, conscientiousness, dan openness to experience) dan Tawakal (yakin pada Allah, tidak khawatir, dan beribadah) terhadap variabel dependen yaitu grit mahasiswa Fakultas Psikologi UIN Jakarta dalam menjalani mata kuliah statistik. Kesimpulan lain yang dapat ditarik secara terpisah adalah bahwa empat variabel independen memiliki pengaruh signifikan terhadap grit siswa, yaitu tipe kepribadian conscientiousness, yakin pada Allah, tidak khawatir, dan beribadah.

\section{Diskusi}

Hasil pada pengaruh variabel HEXACO terhadap grit mendukung penelitian yang dilakukan Durso-Finley (2016) yang ditujukan untuk melihat pengaruh HEXACO terhadap GPA atau nilai akhir perkuliahan. Namun, hanya ada satu dimensi yang signifikan yaitu sama dengan penelitian ini, conscientiousness. Dapat ditarik tali kesimpulan bahwa conscientiousness di dalam HEXACO mempunyai pengaruh terhadap jiwa kerja keras dan fokus pada tujuan jangka panjang di dalam grit untuk nantinya mahasiswa bisa meraih IPK atau nilai akhir perkuliahan yang baik.

Banyak hasil penelitian yang menujukkan bahwa kepribadian merupakan prediktor yang kuat terhadap grit. Angela Duckworth sebagai penggagas utama variabel grit, berhasil membuktikkan bahwa personality types menjadi prediktor grit di dalam pengembangan skala Grit-S (2007) dan GritO (2007). Ini tidak terlepas dari landasan berpikir bahwa kegigihan/persistence yang baru-baru ini dimasukkan menjadi dimensi di dalam grit dapat mewakili hingga menjelaskan seluruh perilaku individu (Ryan, 1939).

Dimensi conscientiousness pada HEXACO berpengaruh signifikan terhadap grit. Dengan hubungan yang positif, maka semakin tinggi kecenderungan kepribadian conscientiousness, semakin tinggi memengaruhi grit pada dirinya. Di mana orang yang mempunyai kecenderungan conscientiousness ditampilkan dengan jiwa disiplin dalam mencapai tujuan, mengupayakan akurasi, 
dan kesempurnaan dalam tugas mereka. Conscientiousness juga dijabarkan dalam penelitian Duckworth \& Quinn (2009) sebagai satu tipe kepribadian yang mempunyai semangat dan selalu berusaha meraih prestasi (achievement striving). Hal ini juga bisa menandakan bahwa orang tersebut memahami long-term goal atas apa yang dirinya lakukan dan menjadi ciri hadirnya nilai grit dalam diri orang tersebut.

Variabel lain yang memberikan pengaruh signifikan terhadap grit adalah tawakal. Tiga dimensi dari variabel tawakal diketahui memiliki pengaruh yang signifikan setelah ditinjau dan diuji sebagai independent variable. Variabel tidak khawatir menujukkan pengaruh paling tinggi terhadap grit dengan signifikansi sebesar 0.179 dan $p$-value 0.009 ( $p<0.05$ ). Hubungan positif ini juga seperti yang diharapkan peneliti karena sesuai dengan asumsi bahwa ketika seseorang memiliki tingkat ketidakkhawatiran yang tinggi, maka orang tersebut juga semakin memantapkan usaha dan kerja kerasnya dalam mengerjakan sesuatu tanpa ada rasa ragu dan/atau takut. Individu yang bertawakal juga akan mengerti bahwa saat dia bekerja keras, di situlah juga ia harus fokus pada tujuan yang hendak dicapai. Tidak perlu takut gagal dan salah, karena ia percaya bahwa apapun yang akan datang adalah di luar kuasa dari dirinya.

Selain itu, menurut Habibah, Lestari, Oktaviana, \& Nashori (2018) ketika seseorang memiliki ketenangan dalam jiwa karena adanya pemahaman tawakal dalam dirinya, maka akan menghasilkan kemampuan untuk merespon pengalaman yang sulit. Ciri tersebut adalah kriteria yang diharapkan dari individu dengan grit tinggi, di mana dirinya mampu beradaptasi dan berjuang melewati suatu keadaan yang sulit atau menantang (Georgoulas-Sherry \& Kelly, 2019).

Variabel lain di dalam tawakal yang juga berpengaruh signifikan terhadap grit adalah yakin kepada Allah dengan signifikansi sebesar -0.173 dan $\mathrm{p}$-value $0.019(\mathrm{p}<0.05)$. Variabel ini diharapkan menyumbang pengaruh dengan arah hubungan positif terhadap grit dengan artian jika individu semakin yakin kepada kuasa Allah, maka grit juga akan semakin tinggi. Namun, hasil penelitian ini menunjukkan bahwa pengaruh yang didapatkan adalah negatif. Sehingga dapat dikatakan bila individu memiliki tingkat keyakinan pada Allah yang rendah akan menghasilkan nilai grit yang tinggi, begitu pula sebaliknya.

Mujib (2017) menjelaskan secara singkat sifat tawakal yaitu bukanlah pasif dan pesimistik, melainkan aktif dan optimistik. Menurutnya, tawakal dilakukan setelah berusaha secara maksimal dalam meraih suatu urusan, tetapi karena keterbatasan manusia, maka usaha itu dihentikan dan diserahkan sepenuhnya kepada Allah. Dari sini dapat dipahami bahwa di dalam pembelajaran statistika yang menjadi topik penelitian, responden yaitu mahasiswa Fakultas Psikologi UIN Jakarta belum bisa mengimplementasikan nilai tawakal secara penuh. Kasus yang terjadi bisa berupa individu akan bekerja keras dan belajar secara tekun karena dia tidak percaya akan bantuan Allah dan hanya meyakini kemampuan dirinya sendiri. Begitu pula sebaliknya, individu yang diindikasikan bernilai tawakal tinggi, ternyata hanya memasrahkan diri tanpa adanya usaha terlebih dahulu sehingga inilah yang dimaksud pasif dan pesimistik.

Hasil yang menujukkan adanya hubungan negatif antara keyakinan pada Allah dan grit ini bertentangan dengan penelitian dari Javanmard (2013) yang mengemukakan bahwa suatu keyakinan individu pada Tuhan (personal beliefs) justru bisa meningkatkan resiliensi dan hardiness yang bisa juga berlaku sebagai ciri individu yang gigih. Namun, hasil ini juga bisa dipahami melalui penelitian Wong-McDonald \& Richard L. Gorsuch (2000) yang menggambarkan bahwa konstruk dan indikator penyerahan urusan kepada Tuhan adalah sebagai coping-style. Pemahamannya bisa bermakna sebagai suatu bentuk menyerah atau lepas tangan sepenuhnya dari individu. Sehingga, apabila 
individu memiliki nilai yang tinggi pada tawakal, maka dimaksudkan bahwa ia menyerah begitu saja pada Allah dan sebagai bentuk pelarian atau coping-style individu tanpa adanya usaha terlebih dahulu.

Variabel terakhir di dalam tawakal yang juga turut berpengaruh signifikan terhadap grit adalah beribadah dengan signifikansi sebesar 0.187 dan $\mathrm{p}$-value 0.008 ( $\mathrm{p}<0.005$ ). Beribadah dalam penelitian ini bisa dipahami sebagai cerminan langsung dari karakter individu bertawakal. Karena di dalamnya memuat perilaku berharap dan pasrah yaitu melalui doa atau ritual peribadatan. Ketaatan dan kekhusyuan saaat beribadah kepada Yang Maha Esa diasumsikan selalu beriringan dan dinamis dengan seluruh usaha yang dilakukannya. Tawakal secara keseluruhan harus dilakukan setelah adanya sebab (Mujib, 2017), yaitu bisa berupa usaha keras hingga tidak ada lagi yang bisa dilakukannya selain berharap kepada Yang Maha Kuasa. Menunaikan ibadah juga dimaknai sebagai upaya individu untuk bertahan menghadapi kenyataan hidup, mengokohkan tekad, serta memupuk rasa semangat. Karena di dalam beribadah, seseorang tahu bahwa dia berada di dalam lindungan dan naungan Allah dan ia percaya Allah akan selalu menolongnya (Najati, 2003).

Adapun variabel lain yang terbukti tidak memiliki pengaruh signifikan terhadap grit pada penelitian ini ialah lima dimensi dari tipe kepribadian HEXACO. Pertama adalah dimensi tipe kepribadian honesty-humility. Dimensi kepribadian ini memiliki ciri faktor diri berupa kejujuran, tulus, adil, sederhana, menghindari watak serakah (de Vries, 2013), menekankan pada nilai kepercayaan, dan menghindari kecurangan (Ashton, et al., 2004). Hal ini dapat dijelaskan jika individu memiliki nilai honesty-humility maka cenderung akan berusaha pada ambang batas wajar dirinya dan cenderung akan sering mencukupkan kerja kerasnya dalam melakukan sesuatu dibandingkan dengan orang lain. Selain itu, bisa saja individu yang memiliki nilai honesty-humility tinggi lebih sederhana dalam goal oriented bagi dirinya saat memiliki satu tujuan yang hendak dicapai. Sehingga dalam penelitian ini tidak terpenuhi dan tidak menghasilkan pengaruh langsung dari honesty-humility terhadap grit. Hal ini sangat memungkinkan karena belum terpenuhinya kedua dimensi di dalam grit dari karakteristik individu honesty-humility, yaitu bekerja keras dan memahami tujuan jangka panjang.

Selain itu, penelitian dari Ceschi, et.al., (2016) yang menemukan hasil spesifik bahwa individu dengan kecenderungan honesty-humility memiliki hasil mudah kelelahan saat melakukan sesuatu. Sehingga, bisa terjadi pada responden penelitian ini bahwa mahasiswa dengan kecenderungan honesty-humility enggan untuk bekerja keras dan memilih untuk berusaha semampunya dalam topik penelitian yaitu mempelajari statistik karena dirinya memilih untuk menghindari rasa kelelahan dalam belajar tersebut.

Dimensi kedua yang tidak memiliki pengaruh signifikan terhadap grit adalah emotionality. Tipe kepribadian yang ini digambarkan dengan karakter ketakutan akan bahaya fisik, mengalami kecemasan dalam menanggapi tekanan hidup, merasakan kebutuhan akan dukungan emosional dari orang lain, dan merasakan empati maupun keterikatan sentimental dengan orang lain. Sekali pun pada penelitian ini belum bisa mengungkap hubungan negatif antara tipe emotionality dan grit, namun deVries, et.al., (2016) mengemukakan bahwa emotionality memang akan menjadikan individu merasa tidak berdaya dan menghindari situasi yang tidak nyaman. Inilah yang menjadi asumsi dari peneliti karena grit membutuhkan karakteristik individu yang berjuang berkali-kali lalu selalu bangkit dalam menghadapi tantangan.

Tipe emotionality memiliki tendensi yang kuat untuk mengalami ketakutan (Rolison, Hanoch, \& Gummerum, 2013). Hal ini yang peneliti pahami bahwa individu dengan muatan emotionality tinggi akan mencoba sebisa mungkin menghindari ketidakberhasilan atau bahkan tidak mau berproses. 
Dirinya menampilkan perasaan mudah cemas, takut akan kegagalan, dan mengatakan bahwa dia tidak bisa menjalani atau menghadapi tantangan seorang diri.

Dimensi ketiga yang tidak memiliki pengaruh signifikan terhadap grit adalah extraversion. Tipe kepribadian yang ini digambarkan dengan karakter individu yang aktif bersosialisasi, berani, antusias dan optimis. Di luar itu semua, deVries, Tybur, Pollet, \& van Vugt (2016) menjabarkan bahwa extraversion kemungkinan mengalami keterbatasan waktu atau kurangnya atensi urusan pribadi karena selalu bersosialisasi dan mengambil dominasi dalam kelompoknya. Oleh karena itu, rasanya tepat bila memprediksikan individu extraversion akan mudah bersosialisasi, namun terasa kesulitan saat memanajemen waktu bagi urusan pribadinya. Padahal, di dalam grit adalah titik penting ketika dirinya bisa konsistensi dalam jangka waktu panjang untuk menjaga orientasi tujuan (consistency of interest).

Dimensi terakhir yang tidak memiliki pengaruh signifikan terhadap grit adalah agreeableness dan openness to experience. Dimensi agreeableness memiliki karakter mudah mengampuni kesalahan orang lain, toleran dalam menilai dan menerima pendapat orang lain, bersedia berkompromi, dan kooperatif, serta dapat dengan mudah mengendalikan emosi mereka. (Ashton, et al., 2004). Sedangkan openness to experience adalah dimensi HEXACO yang menyukai keindahan, menggunakan imajinasinya secara bebas dalam kehidupan sehari-hari, dan menaruh minat pada gagasan atau orang yang tidak biasa.

Hasil penelitian yang mengatakan tidak ada pengaruh keduanya terhadap grit adalah sama seperti yang diharapkan oleh peneliti. Karena diperkirakan kedua dimensi ini hanya akan muncul pada suatu kondisi tertentu sehingga tidak bisa ditunjukkan selama proses kegigihan yang diperlukan dengan jangka waktu panjang karena dibarengi dengan long-term orientation dari grit di dalam individu. Berangkat dari berbagai dugaan atau asumsi peneliti, diharapkan adanya penelitian lanjutan untuk mendapatkan hasil yang lebih baik dan komprehensif.

\section{Daftar Pustaka}

Abd Hamid, H. S., \& Sulaiman, M. K. (2014). Statistics Anxiety and Achievement in a Statistics Course among Psychology Students. International Journal of Behavioral Science, 55-66.

Akos, P., \& Kretchmar, J. (2017). Investigating Grit at a Non-Cognitive Predictor of College Success. The Review of Higher Education, 163-186.

Ashton, M. C., Lee, K., Perugini, M., Szarota, P., de Vries, R. E., Di Blas, L., . . De Raad, B. (2004). A six-factor structure of personality-descriptive adjectives: Solutions from psycholexical studies in seven languages. Journal of Personality and Social Psychology, 356-366.

Ceschi, A., Sartori , R., Dickert, S., \& Costantini, A. (2016). Grit or Honesty-Humility? New Insights into the Moderating Role of Personality between the Health Impairment Process and Counterproductive Work Behavior. Frontiers in Psychology.

Coomer, T. L. (2016). Personality, grit, and psychological capital as they relate to sales performance. Disertation. Oklahoma State University.

Datu, J. A., Yuen, M., \& Chen, G. (2016). Grit and Determination: A Review of Literature With Implications for Theory and Research. Journal of Psychologists and Counsellors in Schools, $1-9$.

de Vries, R. E. (2013). The 24-item Brief HEXACO Inventory (BHI). Journal of Research in Personality, 871-880.

deVries, R. E., Tybur, J. M., Pollet, T. V., \& van Vugt, M. (2016). Evolution, Situational Affordances, and the HEXACO Model of Personality. Evolution and Human Behavior.

Duckworth, A. L., Peterson, C., Matthews, M. D., \& Kelly, D. R. (2007). Grit: Perseverance and passion for long-term goals. Journal of Personality and Social Psychology, 1087-1101. 
Duckworth, A., \& Quinn, P. D. (2009). Development and Validation of the Short Grit Scale (GRITS). Journal of Personality Asessment, 166-174.

Georgoulas-Sherry, V., \& Kelly, D. R. (2019). Resilience, Grit, and Hardiness: Determining the Relationships amongst these Constructs through Structural Equation Modeling Techniques. Journal of Positive Psychology \& Wellbeing, 165-178.

Gupta, N., \& Kumar, S. (2015). Significant predictors for resilience among a sample of undergraduate students: Acceptance, forgiveness and gratitude. Indian Journal of Health and Wellbeing, 188-191.

Habibah, R., Lestari, S. D., Oktaviana, S. K., \& Nashori, F. (2018). Resiliensi pada Penyintas Banjir Ditinjau dari Tawakal dan Kecerdasan Emosi. Jurnal Psikologi Islam dan Budaya, 29-36.

Hill, K., \& Wigfield, A. (1984). Test anxiety: a major educational problem and what can be done about it. The Elementary School Journal, 105-126.

Jachimowicz, J. M., Wihler, A., Bailey, E. R., \& Galinsky, A. D. (2018). Why grit requires perseverance and passion to positively predict performance. Psychology and Cognitive Sciences Journal, 9980-9985.

Javanmard, G. H. (2013). Religious Beliefs and Resilience in Academic Students. Procedia Social and Behavioral Sciences, 744-748.

Lin, C.-L., \& Chang, C.-Y. (2017). Personality and Family Context in Explaining Grit of Taiwanese High School Students. EURASIA Journal of Mathematics Science and Technology Education, 2197-2213.

Macher, D., Manuela, P., \& Papousek, I. (2012). Statistics anxiety, trait anxiety, learning behavior, and academic performance. European Journal of Psychology of Education, 483-498.

Mendez, I. (2015). The effect of the intergenerational transmission of noncognitive skills on student performance. Economics of Education Review, 78-97.

Mujib, A. (2017). Teori Kepribadian Perspektif Psikologi Islam Edisi Kedua. Depok: RajaGrafindo Persada.

Najati, M. U. (2003). Psikologi Dalam Tinjauan Hadis Nabi. Jakarta: Mustaqiim.

Onwuegbuzie, A., \& Wilson, V. (2003). Statistics anxiety: nature, etiology, antecedents, effects, and treatments - a comprehensive review of the literature. Teaching in Higher Education, 195-209.

Rojas, J. P., Reser, J. A., Usher, E. L., \& Toland, M. D. (2012). Psychometric Properties of the Academic Grit Scale. Spring Research Conference. Louisville: University of Kentucky.

Rolison, J. J., Hanoch, Y., \& Gummerum, M. (2013). Characteristics of Offender: HEXACO Model of Personality as a Framework for Studying Offenders Personality. The Journal of Forensic Psychiatry \& Psychology, 71-82.

Sartika, A., \& Kurniawan, I. N. (2015). Skala Tawakal Kepada Allah: Pengembangan Ukuranukuran Psikologis Surrender to God Dalam Perspektif Islam. Psikologika, 129-142.

Sugiyono. (2007). Statistika Untuk Penelitian. Bandung: CV ALFABETA.

Vainio, M. M., \& Daukantaite, D. (2015). Grit and Different Aspects of Well-Being: Direct and Indirect Relationships via Sense of Coherence and Authenticity. Journal Happiness Study. 